\title{
Morphological, phylogenetic and pathogenicity characterisation of Fusarium species associated with wilt disease of pumpkin (Cucurbita pepo Linnaeus)
}

\author{
Asma Aris' ${ }^{1}$ Zainap Ab Easa Hasan ${ }^{1}$, Shamarina Shohaimi ${ }^{1}$, Noor Baity Saidi ${ }^{2}$, Nur Ain Izzati Mohd Zainudin ${ }^{1}$ \\ ${ }^{1}$ Department of Biology, Faculty of Science, Universiti Putra Malaysia, 43400 Serdang Selangor, Malaysia \\ ${ }^{2}$ Department of Molecular and Cell Biology, Faculty of Biotechnology and Biomolecular Science, Universiti Putra Malaysia, \\ 43400 Serdang Selangor, Malaysia
}

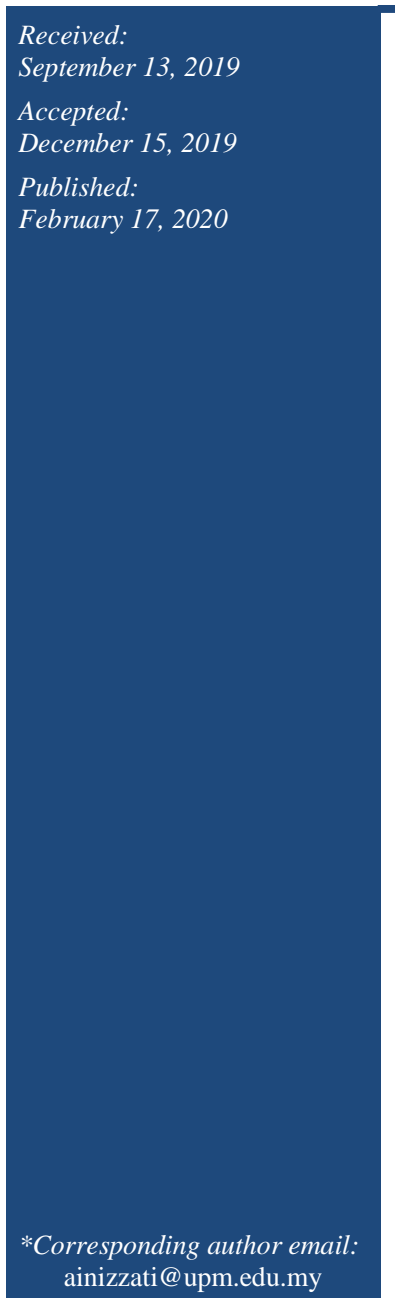

\begin{abstract}
Fusarium is a well-known soil-borne fungus where most species belonged in this genus is prominently phytopathogenic. Nevertheless, this pathogenic species has affected the production of pumpkin worldwide. This study underlines the morphological, phylogeny and pathogenicity characteristics of Fusarium for a better disease-control strategy. Twenty-six Fusarium isolates were collected from wilt infected pumpkin in various locations of Peninsular Malaysia. From the combinations of morphological and molecular identifications, four species were identified as $F$. oxysporum ( 2 isolates), $F$. solani (4 isolates), $F$. proliferatum ( 7 isolates) and $F$. incarnatum (13 isolates). Microscopic and macroscopic observation visualized distinct characteristics of the identified Fusarium species. Sequence analyses of tefl $\alpha$ and $\beta$-tub genes inferred by maximum likelihood tree resulted in distinct section-specific characteristics. Meanwhile, pathogenicity test of Fusarium isolates presented by the seed inoculation produced various degrees of severities. Fusarium solani $\mathrm{C} 2526 \mathrm{P}$ recorded the highest severity of $93.8 \%$ after 30 days of post inoculation (dpi). Symptoms have been identified as early as 10 dpi producing stunted growth of the plants. On the other hand, Fusarium oxysporum D2532P recorded 85.3\% disease severity. Pathogenic Fusarium caused stunted growth, chlorosis, wilting and necrosis especially at the root of pumpkin plants. This study provides valuable information and methods to manage wilt infected pumpkin in the future.
\end{abstract}

Keywords: Fusarium wilt, Cucurbita pepo, Phylogeny, Pathogenicity

\section{How to cite this:}

Aris A, Hasan ZAE, Shohaimi S, Saidi NB and Zainudin NAIM, 2020. Morphological, phylogenetic and pathogenicity characterisation of Fusarium species associated with wilt disease of pumpkin (Cucurbita pepo Linnaeus). Asian J. Agric. Biol. 8(1):75-84. DOI: $10.35495 / a j a b .2019 .07 .319$

This is an Open Access article distributed under the terms of the Creative Commons Attribution 3.0 License. (https://creativecommons.org/licenses/by/3.0), which permits unrestricted use, distribution, and reproduction in any medium, provided the original work is properly cited.

\section{Introduction}

Pumpkin (Cucurbita pepo Linnaeus) belongs to the Cucurbitaceae family. Since the last five years, an average of $2.29 \%$ of pumpkin has been produced out of total main crops in Malaysia (MOA, 2018). Previously known as the most variable species in the kingdom of plant, this crop is enthusiastically traded for the multifunction of seed oil (Ferriol et al., 2003; Stevenson et al., 2007; Medjakovic et al., 2016). 
Commonly, pumpkin is consumed as food and applied in ethno-medicinal applications in several countries such as China, Mexico and India (Alarcon-Aguilar et al., 2002; Aggarwal and Kotwal, 2009). However, this highly demanded crop is being attacked by various fungal infections mainly in the field.

Fusarium wilt disease is recognized as a yield-limiting factor in various cucurbit productions. This disease can be perceptible by stunting, yellowing of lower leaves, progressing wilting, defoliation, necrosis of the vascular tissue and death of plants (Chehri et al., 2011; Caroline and Olubukola, 2013; Redda et al., 2018). The most important pathogens causing the disease are Fusarium oxysporum and Fusarium solani. These pathogens could survive in the soil for several years in a form of chlamydospores (Callagan et al., 2016) and have become the main limiting factor in managing disease dissemination. Thus, characterization of pathogenic Fusarium is essential for integrating disease management to limit the extension of its host range.

Several pathogenic species in the genus Fusarium are specialized with respect to their host specificity formerly known as formae speciales $(f . s p$.) (Snyder and Hansen, 1940). This specialization was recognized as the physiological capabilities of Fusarium strains onto one or a few species of plant. The pathogenic species is considered arduous to be controlled due to several aspects such as its ability to produce resistance structures, resistance to fungicides, manipulation on host defence responses and the ability to produce mycotoxins (Van Dam et al., 2016; Moreno-Velandia, et al., 2019). However, several species belong in the genus were considered saprophytic while others pathogenic. Identification and recognition of the primary invader could reduce the infection risks.

Therefore, the objectives of this study were to isolate and identify Fusarium species associated with wiltinfected pumpkin and to ascertain the pathogenicity test of the isolated Fusarium species.

\section{Material and Methods}

\section{Fungal isolation}

Pumpkin was obtained from five various locations throughout Peninsular Malaysia including Maran and Cameron Highland in Pahang, Tok Bali in Kelantan, Tanjung Karang in Selangor and Tangkak in Johor. Infected leaves and fruits were chosen for fungal isolation and cut into pieces of $1 \mathrm{~cm} \mathrm{x} 1 \mathrm{~cm}$. Infected tissues were soaked in $0.5 \%$ sodium hypochlorite $(\mathrm{NaOCl})$ (Chlorox, Oakland, USA) and rinsed twice with sterile distilled water (Liu et al., 2017). Tissues were dried using sterile filter paper and placed on peptone pentachloronitrobenzene agar (PPA) (SigmaAldrich, Missouri, USA) followed by incubation for 5 days (Summerell et al., 2003). The cultures were purified by streak plate technique onto potato dextrose agar (PDA) and incubated for 5 days at $28 \pm 2{ }^{\circ} \mathrm{C}$ (Leslie and Summerell, 2006).

\section{Morphological characterisation}

Morphological characterisation was divided into microscopic and macroscopic observations on each isolate. For microscopic examination, cultures were grown on carnation leaf agar (CLA) (Leslie and Summerell, 2006) and incubated for 7 days at $28 \pm 2$ ${ }^{0} \mathrm{C}$. Matured culture was observed under light microscope CX2Li (Olympus, Tokyo, Japan). With the same observation method, Fusarium cultures grown on water agar (WA) were also examined. Characters such as the conidia size, shape and number of septate, presence of chlamydospore, phialide and hypha were observed and recorded (Leslie and Summerell, 2006). For macroscopic examination, cultures were grown on PDA for 7 days at $28 \pm 2{ }^{\circ} \mathrm{C}$. Macroscopic characters included in this study were pigmentation, colony features and presence of sporodochia.

\section{DNA extraction}

Fusarium isolates were grown on PDA for 5 days (28 $\left.\pm 2{ }^{0} \mathrm{C}\right)$. With micropipette tip, the mycelia of the culture were scratched prior to DNA extraction. The genomic DNA was extracted by Ultra Clean ${ }^{\circledR}$ Microbial DNA isolation kit (MO-BIO, Carlsbed, CA, USA) according to the procedures by manufacturer.

\section{Amplification of tef1 $\alpha$ and $\beta$-tubulin genes}

The DNA fragments were amplified by $\mathrm{T} 100^{\mathrm{TM}}$ Thermal Cycler (Bio-Rad, California, USA). The 20 $\mu \mathrm{L}$ reaction mastermix (PROMEGA, Madison, WI, USA) consists of $4 \mu \mathrm{L}$ of $5 \mathrm{x}$ Green GoTaq buffer, 2 $\mu \mathrm{L}$ of $0.2 \mathrm{mM}$ deoxynucleotide triphosphate (dNTPs), $2 \mu \mathrm{L}$ of $0.2 \mathrm{mM}$ magnesium chloride $\left(\mathrm{MgCl}_{2}\right), 0.1 \mu \mathrm{L}$ of Taq Polymerase, $1 \mu \mathrm{L}$ of DNA template and $8.9 \mu \mathrm{L}$ nuclease free water. One $\mu \mathrm{L}$ of $0.1 \mathrm{mM}$ TEF primer set containing EF1 (5'ATGGGTAAGGAGGACAAGAC-3') and EF2 (5'GGAAGTACCAGTGATCATGTT-3') (Geiser et al., 2004) and beta-tubulin primer set comprising T1 (5'- 
AACATGCGTGAGATTGTAAGT-3) and T2 (5'TAGTGACCCTTGGGCCCAGTTG-3') (O'Donnell and Cigelnik, 1997) were used. Tefl $\alpha$ gene was amplified under following cycles; initial denaturation at $94{ }^{\circ} \mathrm{C}$ for $90 \mathrm{~s}, 35$ cycles of denaturation at $95{ }^{\circ} \mathrm{C}$ for $35 \mathrm{~s}$, annealing at $57{ }^{\circ} \mathrm{C}$ for $55 \mathrm{~s}$, extension at 72 ${ }^{0} \mathrm{C}$ for $90 \mathrm{~s}$ and final extension at $72{ }^{\circ} \mathrm{C}$ for $10 \mathrm{~min}$. The PCR program of beta-tubulin was held through the following cycles; initial denaturation at $94{ }^{\circ} \mathrm{C}$ for $1 \mathrm{~min}, 35$ cycles of denaturation at $94{ }^{\circ} \mathrm{C}$ for $35 \mathrm{~s}$, annealing at $58{ }^{\circ} \mathrm{C}$ for $2 \mathrm{~min}$, extension at $72{ }^{\circ} \mathrm{C}$ for 1 min, final extension at $72{ }^{\circ} \mathrm{C}$ for $10 \mathrm{~min}$ and soaked at $4{ }^{0} \mathrm{C}$ (Kumar et al., 2016).

\section{Gel electrophoresis}

Amplified DNAs were detected by gel electrophoresis. A $100 \mathrm{bp}$ ladder was loaded into $1.2 \%$ agarose gel (Promega Corporation, USA) containing $20 \mathrm{~mL}$ of Tris-Borate-EDTA (TBE) (Hafizi et al., 2013). The gel was stained with fluorosafe dye (1st Base Company, First Base Laboratories Sdn. Bhd. Seri Kembangan, Selangor, Malaysia). Gel integration was captured by G:BOX Syngene under ultra violet (UV) radiation.

\section{Nucleotide sequencing and phylogenetic analysis}

PCR products were submitted to MyTACG Bioscience Company, Malaysia, for purification and sequence analysis. The nucleotide sequence dataset of tefl $\alpha$ and $\beta$-tub was aligned by ClustalW using Molecular Evolutionary Genetics Analysis 7.0 (MEGA). Alignments were manually modified to exclude all ambiguous sections from analysis. Basic Local Alignment Search Tool (BLAST) gene polymorphism analysis in comparison with databases from National Centre of Biotechnology Information (NCBI) resulted in related genus species including $F$. incarnatum NRRL 31160, F. oxysporum NRRL 25369, $F$. proliferatum NRRL 53578 and $F$. solani FMR 8021 (Otero-Colina et al., 2010; Azor et al., 2007) as references for the alignment. Aspergillus niger CBS513.88 was used as an outgroup. Maximum likelihood (ML) was inferred to a phylogenetic tree displaying support value of more than $80 \%$ (Watanabe et al., 2011).

\section{Conidial suspension}

A total of 26 Fusarium isolates were cultured on PDA at $28 \pm 2{ }^{\circ} \mathrm{C}$ for 5 days prior to inoculum preparation. Matured cultures were added with $10 \mathrm{~mL}$ sterile distilled water followed by tender scratch on the filamentous mycelia using sterile micropipette tip. Fungal inoculum of $200 \mathrm{~mL}$ was prepared to a final concentration of $2 \times 10^{6}$ conidia/ $\mathrm{mL}$ as adopted from Chehri et al. (2011). The mycelial sheets and residues of the media were filtered using sterile cheese cloth and transferred into a $500 \mathrm{~mL}$ conical flask.

\section{Seed inoculation}

The seeds of pumpkin var. Gold Butter (Green World Genetics Sdn. Bhd., Kuala Lumpur, Malaysia) were sterilised according to Zhang et al. (2012) by soaking into $10 \%$ sodium hypochlorite $(\mathrm{NaOCl})$ and rinsed twice with sterile distilled water. Sterilised seeds were then inoculated by soaking into $200 \mathrm{~mL}$ fungal conidia suspension for 12 hours in an incubator shaker at 100 $\mathrm{rpm}$ in $30 \pm 1{ }^{\circ} \mathrm{C}$ (Sukanya and Jayalakshmi, 2017). Inoculated seeds were sown into $1 \mathrm{~kg}$ soil containing a mixture ratio of (3:2:1 = topsoil: manure: river sand) pre-autoclaved according to Mahmood et al. (2014). Plant treatments were performed in randomised complete design (RCD) in the UPM Glasshouse. Each isolate was prepared with 12 plant replicates and grown within $12 / 12 \mathrm{hrs}$ at $32 \pm 1{ }^{\circ} \mathrm{C}$ days and $28 \pm 1^{\circ} \mathrm{C}$ nights with humidity of $72 \%$ for 30 days. Plant physiological parameters and disease severity index (DSI) were calculated followed by data collection.

Table-1: Disease scales for Fusarium wilt assessment.

\begin{tabular}{|c|l|}
\hline Scales & \multicolumn{1}{|c|}{ anference } \\
\hline 0 & Seed germinated, no symptoms of wilt. \\
\hline 1 & $\begin{array}{l}\text { Seed germinated, wilt symptoms, 1-24\% of } \\
\text { leaves showing slight chlorosis. }\end{array}$ \\
\hline 2 & $\begin{array}{l}\text { Seed germinated, wilt symptoms, abnormal } \\
\text { growth with 25-49\% of leaves showing } \\
\text { chlorosis and/or curvature. }\end{array}$ \\
\hline 3 & $\begin{array}{l}\text { Seed germinated, wilt symptoms, abnormal } \\
\text { growth with 50-74\% of leaves wilting, chlorosis } \\
\text { and/or limited necrosis. }\end{array}$ \\
\hline 4 & $\begin{array}{l}\text { Seed not germinated or seed germinated with } \\
\geq 75 \% \text { of the leaves showing wilt symptom. }\end{array}$ \\
\hline
\end{tabular}

${ }^{a}$ wilt symptoms - wilting, severe stunting and necrosis with premature defoliation that often result in the death of plants.

\section{Disease assessment and data analysis}

The cultivation was observed for 30 days of post inoculation (dpi). The progress of symptoms appearance was carried out every 5 days. After 30 dpi, the emergence of any particular wilt symptoms was assessed according to disease scale (Table 1) conducted by Schoonhoven and Pastor-Corrales 
(1994) as well as Raupach et al. (1996) with slight modifications.

The disease severity index was calculated for each isolate according to the parameters in the disease scale (Mwaniki et al., 2011).

$$
\mathrm{DSI}=\frac{\sum(\mathrm{A} \times \mathrm{n})}{\Sigma(\mathrm{B})} \times 100
$$

A: Disease scales

$\mathrm{n}$ : Number of plants in specific scale

B: total number of plants

The significant disease severity among isolates was tested by the analysis of variance (ANOVA) followed by Duncan's multiple test $(p<0.05)$ from Statistical Package for Social Sciences (SPSS).

\section{Results}

\section{Morphological characteristics}

A total of 26 isolates were recovered from Maran and Cameron Highland in Pahang, Tok Bali in Kelantan, Tanjung Karang in Selangor and Tangkak in Johor. Five species were identified as $F$. oxysporum (2 isolates), $F$. solani (4 isolates), $F$. proliferatum (7 isolates) and $F$. incarnatum (13 isolates) based on morphological characteristics according to synoptic keys for species identification.

Morphologically, all species presented primary characters, which include macroconidia, microconidia and chlamydospore. All 26 isolates were observed microscopically and macroscopically; this includes size, shape and number of septate of the macroconidia, microconidia and chlamydospore, position of conidia, pigmentation and colony features. Chlamydospores are produced in all Fusarium species colonies except for $F$. proliferatum (Table 2 ).

Table-2: Microscopic and macroscopic morphologies of Fusarium incarnatum, F. proliferatum, F. solani and $F$. oxysporum isolate isolated from infected-wilt disease of pumpkins

\begin{tabular}{|c|c|c|c|c|}
\hline Fungal species & Fusarium incarnatum & $\begin{array}{c}\text { Fusarium } \\
\text { proliferatum }\end{array}$ & $\begin{array}{c}\text { Fusarium } \\
\text { solani }\end{array}$ & Fusarium oxysporum \\
\hline $\begin{array}{l}\text { Number of } \\
\text { isolates }\end{array}$ & 13 & 7 & 4 & 2 \\
\hline List of isolates & \begin{tabular}{|c|}
$\mathrm{C} 2520 \mathrm{P}, \mathrm{C} 2522 \mathrm{P}, \mathrm{C} 2523 \mathrm{P}$ \\
$\mathrm{C} 2524 \mathrm{P}, \mathrm{C} 2525 \mathrm{P}, \mathrm{C} 2527 \mathrm{P}$ \\
$\mathrm{C} 2528 \mathrm{P}, \mathrm{C} 2529 \mathrm{P}, \mathrm{C} 2531 \mathrm{P}$ \\
$\mathrm{D} 2533 \mathrm{P}, \mathrm{D} 2535 \mathrm{P}$ \\
$\mathrm{D} 2536 \mathrm{P}, \mathrm{D} 2537 \mathrm{P}$ \\
\end{tabular} & $\begin{array}{l}\mathrm{C} 2521 \mathrm{P}, \mathrm{B} 1781 \mathrm{P}, \\
\mathrm{J} 1789 \mathrm{P}, \mathrm{J} 1790 \mathrm{P}, \\
\mathrm{J} 1791 \mathrm{P}, \mathrm{J} 1792 \mathrm{P} \\
\mathrm{J} 1793 \mathrm{P}\end{array}$ & $\begin{array}{l}\text { C2526P, C2530P, } \\
\text { D2534P, B1782P }\end{array}$ & D2532P, C1788P \\
\hline \multicolumn{5}{|c|}{ Microscopic characters; } \\
\hline Macroconidia & $\begin{array}{c}\text { Size of } 29.14-24.44 \mu \mathrm{m}, \\
\text { wide width at the centre to } \\
\text { slender ends, } 3-5 \text { septate. }\end{array}$ & $\begin{array}{c}\text { Size of } 30.73- \\
70.02 \mu \mathrm{m}, \text { most } \\
\text { straight and linear } \\
\text { shape, } 3-5 \text { septate. }\end{array}$ & $\begin{array}{c}\text { Size of } 27.61-30.92 \mu \mathrm{m} \\
\text { almost straight } \\
\text { curvature with rounded } \\
\text { ends, 3-4 septate. }\end{array}$ & $\begin{array}{c}\text { Size of } 30.43-52.17 \mu \mathrm{m}, \\
\text { almost straight curvature } \\
\text { with rounded ends, 3-4 } \\
\text { septate. }\end{array}$ \\
\hline Microconidia & $\begin{array}{c}\text { Size of } 5.02-10.11 \mu \mathrm{m}, \\
\text { ellipsoidal with or without } \\
\text { septate. }\end{array}$ & $\begin{array}{c}\text { Size of } 5.76-10.12 \\
\mu \mathrm{m}, \text { long-chained } \\
\text { microconidia. }\end{array}$ & $\begin{array}{c}\text { Size of } 10.22-20.09 \\
\mu \mathrm{m}, \text { kidney-shaped with } \\
\text { some is multinucleate. }\end{array}$ & $\begin{array}{l}\text { Size of } 6.08-15.14 \mu \mathrm{m} \text {, } \\
\text { usually ellipsoidal shaped. }\end{array}$ \\
\hline Chlamydospore & $\begin{array}{c}\text { Size of } 5.16-12.05 \mu \mathrm{m}, \\
\text { usually triple-chained cell } \\
\text { at the intermediate hypha. }\end{array}$ & absent & $\begin{array}{c}\text { Size of } 6.13-11.18 \\
\mu \mathrm{m}, \text { Single and pair } \\
\text { cells usually located at } \\
\text { terminal of hypha, hold } \\
\text { by long monophialide. }\end{array}$ & $\begin{array}{c}\text { Size of } 8.22-12.17 \mu \mathrm{m}, \\
\text { single cell usually at } \\
\text { intercalary of hypha, } \\
\text { round-shaped. }\end{array}$ \\
\hline \multicolumn{5}{|c|}{ Macroscopic characters; } \\
\hline Pigmentation & White to cream and brown. & $\begin{array}{l}\text { White to cream and } \\
\text { violet. }\end{array}$ & White to cream. & $\begin{array}{l}\text { White to pale violet and } \\
\text { sometimes pale brown. }\end{array}$ \\
\hline Colony features & $\begin{array}{l}\text { Rapidly grown. Very } \\
\text { thick, cotton-like and } \\
\text { floccose aerial mycelia. }\end{array}$ & $\begin{array}{l}\text { Sparse, floccose } \\
\text { and not so thick. }\end{array}$ & Sparse and thin. & $\begin{array}{l}\text { Floccose, sparse and } \\
\text { abundant of aerial } \\
\text { mycelia, cotton-like. }\end{array}$ \\
\hline
\end{tabular}


All species shared a variety of macroconidia shape with slightly curved and tapered towards each ends. The apical end is elongated especially for $F$. proliferatum macroconidia. The basal end is where the conidia were attached and it is slightly short. Fusarium oxysporum and $F$. solani shared similar features of macroconidia, but $F$. solani has bigger in size. Fusarium proliferatum has the only microconidia observed in chain on CLA as early as 4 days of incubation, whilst other species present detach and individual microconidia. CLA is a substrate medium produced by sterilized carnation leaf-pieces that is particularly useful in uniform conidia identification purpose (Nelson et al., 1983).

Among all the species, $F$. incarnatum colonies grown most rapidly on PDA by displayed thick and cottony aerial mycelia. As the colony grown matured of 5 days old, the pigmentation produced on media could be observed. The colours are initially white and changes as it grown matured. Even though, colonies produced quiet similar pigment but feature and thickness of the aerial mycelia differ among species. The pigmentation produced in the media facilitates morphological distinction between species and served as the initial identification. However, the identification based on morphological characteristic was somehow affected by genotype and environmental conditions, which led to instability and complication in species identification. Thus, the identification of Fusarium could achieve a better accuracy as molecular identification is applied upon morphological speciation.

\section{Phylogenetic analysis}

Prior to the construction of presented phylogenetic tree, individual dataset of a single locus was first generated and found to be incongruence to each other. Apart from that, similar dataset constructed did not resolve the high confidence value as high as the stated bootstrap support value. PCR amplification of tefl $\alpha$ and $\beta$-tub genes registered a single fragment on agarose gel electrophoresis ranging from 645 to 918 bp and 500 to $693 \mathrm{bp}$ in size (Figure 1, Table 3).

Table-3: BLASTn analysis of all 26 isolates associated with wilt disease in pumpkins.

\begin{tabular}{|c|c|c|c|c|c|c|}
\hline \multirow[b]{2}{*}{ Isolates } & \multirow[b]{2}{*}{ Location (State, city) } & \multirow[b]{2}{*}{ Species name } & \multicolumn{2}{|l|}{ BT } & \multicolumn{2}{|c|}{ TEF } \\
\hline & & & Sequence length (bp) & Accession no. & $\begin{array}{c}\text { Sequence } \\
\text { length (bp) }\end{array}$ & Accession no. \\
\hline $\mathrm{C} 2520 \mathrm{P}$ & Maran, Pahang & $F$. incarnatum & 578 & MK527240 & 668 & MK519232 \\
\hline $\mathrm{C} 2521 \mathrm{P}$ & Maran, Pahang & $F$. proliferatum & 565 & MK527241 & 649 & MK519233 \\
\hline $\mathrm{C} 2522 \mathrm{P}$ & Maran, Pahang & F. incarnatum & 581 & MK527242 & 670 & MK519234 \\
\hline $\mathrm{C} 2523 \mathrm{P}$ & Maran, Pahang & F. incarnatum & 580 & MK527243 & 670 & MK519235 \\
\hline $\mathrm{C} 2524 \mathrm{P}$ & Maran, Pahang & F. incarnatum & 571 & MK527244 & 810 & MK519236 \\
\hline $\mathrm{C} 2525 \mathrm{P}$ & Maran, Pahang & F. incarnatum & 582 & MK527245 & 661 & MK519237 \\
\hline $\mathrm{C} 2526 \mathrm{P}$ & Maran, Pahang & F. solani & 518 & MK527246 & 674 & MK519238 \\
\hline $\mathrm{C} 2527 \mathrm{P}$ & Maran, Pahang & F. incarnatum & 576 & MK527247 & 663 & MK519239 \\
\hline $\mathrm{C} 2528 \mathrm{P}$ & Maran, Pahang & F. incarnatum & 584 & MK527248 & 660 & MK519240 \\
\hline $\mathrm{C} 2529 \mathrm{P}$ & Maran, Pahang & F. incarnatum & 564 & MK527249 & 665 & MK519241 \\
\hline $\mathrm{C} 2530 \mathrm{P}$ & Maran, Pahang & F. solani & 520 & MK527250 & 679 & MK519242 \\
\hline $\mathrm{C} 2531 \mathrm{P}$ & Maran, Pahang & F. incarnatum & 590 & MK527251 & 662 & MK519243 \\
\hline $\mathrm{D} 2532 \mathrm{P}$ & Tok Bali, Kelantan & F. oxysporum & 568 & MK527252 & 677 & MK519244 \\
\hline $\mathrm{D} 2533 \mathrm{P}$ & Tok Bali, Kelantan & F. incarnatum & 573 & MK527253 & 669 & MK519245 \\
\hline $\mathrm{D} 2534 \mathrm{P}$ & Tok Bali, Kelantan & F. solani & 509 & MK527254 & 679 & MK519246 \\
\hline $\mathrm{D} 2535 \mathrm{P}$ & Tok Bali, Kelantan & F. incarnatum & 575 & MK527255 & 666 & MK519247 \\
\hline $\mathrm{D} 2536 \mathrm{P}$ & Tok Bali, Kelantan & F. incarnatum & 567 & MK527256 & 649 & MK519248 \\
\hline $\mathrm{D} 2537 \mathrm{P}$ & Tok Bali, Kelantan & F. incarnatum & 571 & MK527257 & 662 & MK519249 \\
\hline $\mathrm{B} 1781 \mathrm{P}$ & Tanjung Karang, Selangor & F. proliferatum & 554 & MK527258 & 680 & KT211607 \\
\hline $\mathrm{B} 1782 \mathrm{P}$ & Tanjung Karang, Selangor & F. solani & 514 & MK527259 & 695 & KT211615 \\
\hline $\mathrm{C} 1788 \mathrm{P}$ & Cameron Higland, Pahang & F. oxysporum & 461 & MK527260 & 670 & KT211602 \\
\hline J1789P & Tangkak, Johor & F.proliferatum & 563 & MK527261 & 681 & KT211609 \\
\hline J1790P & Tangkak, Johor & F.proliferatum & 565 & MK527262 & 677 & KT211610 \\
\hline J1791P & Tangkak, Johor & F.proliferatum & 564 & MK527263 & 678 & KT211611 \\
\hline J1792P & Tangkak, Johor & F.proliferatum & 558 & MK527264 & 675 & KT211612 \\
\hline J1793P & Tangkak, Johor & F. proliferatum & 558 & MK527265 & 678 & KT211613 \\
\hline
\end{tabular}



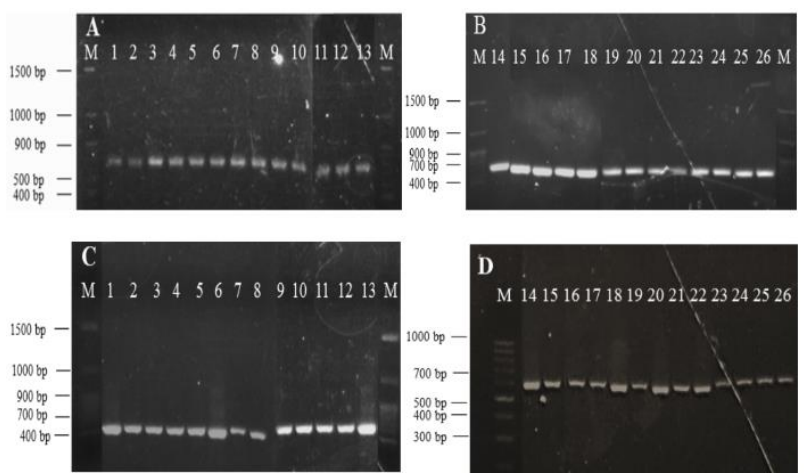

Figure-1: Banding pattern of DNA fragments. A and $B$ : tefl $\alpha$ region, $C$ and $D: \beta$-tubulin region.

Lane 1-13: (C2520P, C2521P, C2522P, C2523P, C2524P， C2525P， C2526P， C2527P， C2528P, C2529P, C2530P, C2531P, D2531P), lane 14-15: (D2532P， D2533P， D2534P， D2535P， D2536P, D2537P, B1781P, B1782P, C1788P, J1789P, J1790P, J1791P, J1792P, J1793P) and M: 100 bp markers.

Based on phylogenetic analysis of combining both genes, four major clades were generated. The first clade comprises four isolates of $F$. solani. Clade II contains seven isolates of $F$. proliferatum. Clades III and IV consist of two isolates of $F$. oxysporum and 13 isolates belong to $F$. incarnatum, respectively. All isolates belong in the first clade were not diverged in nucleotide substitution represented by the horizontal branch compared to the reference sequence (Figure 2).

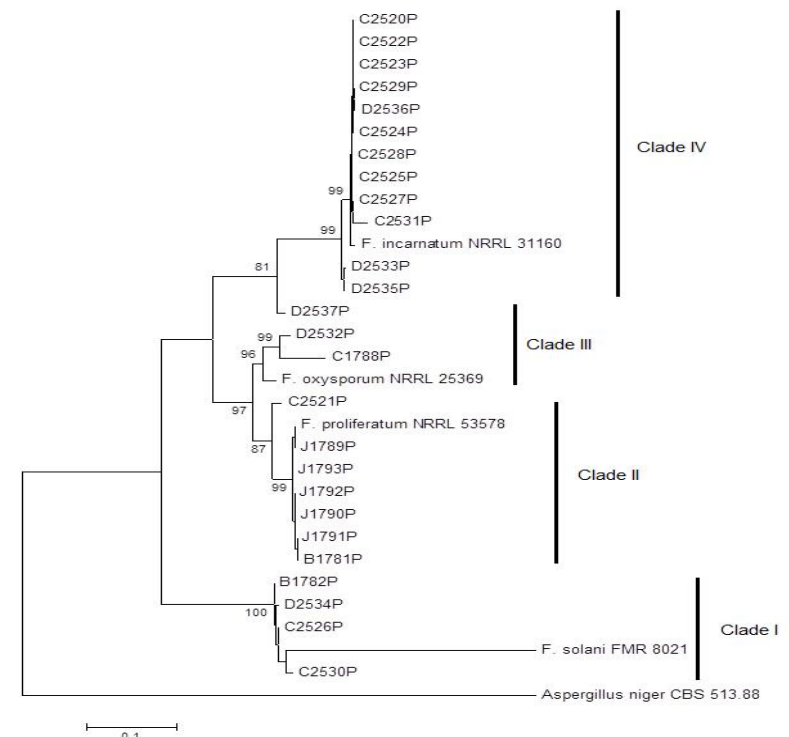

Figure-2: Maximum likelihood trees of Fusarium isolates and related species inferred from the combination of tefl $\alpha$ and $\beta$-tub
Clade I consisted of isolate with highly virulent and pathogenic $F$. solani to pumpkin. Meanwhile, Clade II represents the highest number of moderate virulent of $F$. proliferatum on pumpkin. Clade IV represented the most isolates identified as non-virulent by displaying no observable symptoms on pumpkin plants up to 30 dpi. Based on the phylogenetic topology, it could be inferred to as an indication of Fusarium virulence through evolutionary time.

The use of tefl $\alpha$ and $\beta$-tub sequences into molecular identification has brought sufficient information on Fusarium sp. identification. The Maximum Likelihood tree based on tefl $\alpha$ and $\beta$-tub genes indicated that the species in each clade has a close relationship with each other. Fusarium solani was diverged into a polyphyly relationship from any other species.

\section{Pathogenicity test}

This study reveals that pumpkin plants inoculated with Fusarium isolates produced some levels of disease scale. A total of 26 isolates produced various degree of disease severities on the plants. Within a period of 30 dpi, the pathogenesis of Fusarium species recorded as sufficient duration in order to cause disease invasion besides of pumpkin planting challenges in the cultivation as it requires spacious area for sprawling vines.

Pathogenic Fusarium infected pumpkin plants rapidly. The symptoms were observed on the plants as early as 10 dpi by $F$. solani $\mathrm{C} 2526 \mathrm{P}$. The first symptom appeared as stunted growth. The plants inoculated with $F$. solani $\mathrm{C} 2526 \mathrm{P}$ presented no progression of stem height and leaves area.

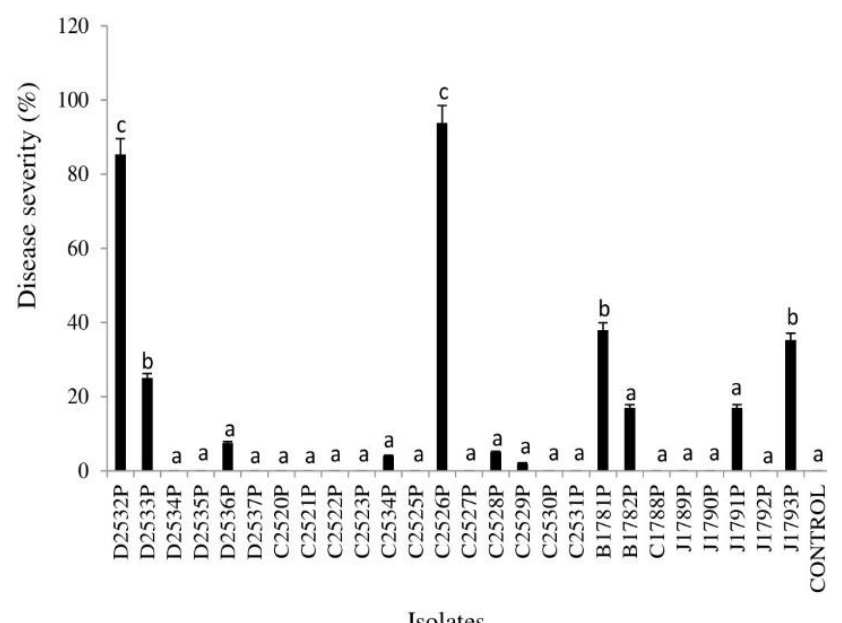

Figure-3: Disease severities of Fusarium isolates inoculated on pumpkin on $30 \mathrm{dpi}$ 
This isolate recorded the highest disease severity of $93.8 \%$ followed by $F$. oxysporum D2532P with disease severity of $85.3 \%$ (Figure 3 ). Three of $F$. proliferatum isolates; B1781P, J1791P and J1793P were identified as moderate virulent. All these three isolates produced average percentages of disease severity of $38.0 \%, 17.0 \%$ and $35.3 \%$, respectively. Fifteen isolates were identified as non-pathogenic with no observable symptoms produced.

The symptoms were initially produced by the stunted growth of the plants. Infection starts progressing with the appearance of chlorosis on the lower leaves in which the leaves were wilted and crumpled. Cross section of the primary root structures displayed necrosis after $30 \mathrm{dpi}$. The lateral roots or the root branches were reduced on the infected plants (Figure 4) compared to the control plants. Fusarium infection is generally limited to the shoot area, but mainly at the root area. Therefore, severe symptoms can be observed at the root cortex.

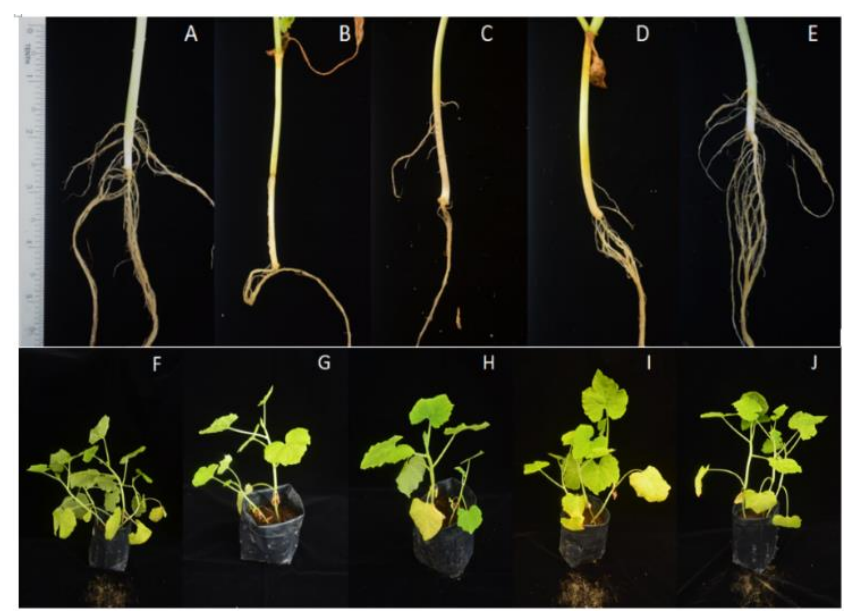

Figure-4: Pumpkin roots and plants on 30 dpi. A and $\mathrm{F}$ : $\mathrm{dH}_{2} \mathrm{O}$ (control), $\mathrm{B}$ and $\mathrm{G}$ : $F$. oxysporum D2532P, C and H: $F$. solani C2526P, D and I: $F$. proliferatum J1793P, $\mathrm{E}$ and $\mathrm{J}: F$. incarnatum C2522P on 30 dpi

\section{Discussion}

Molecular identification has provided various dependable outputs of Fusarium identification compared to morphological characterisation. Previously, several markers including protein-coding regions and nuclear ribosomal DNA (rDNA) (Liu et al., 2015; Sanders and Rodriguez, 2016; Kusai et al., 2018; Turrini et al., 2017) were used and resulted in a high quality species identification especially for a closely related species. Protein coding genes have showed a rapid nucleotide substitution rate and subsequently high resolution for closely related species or among conspecific strains (Watanabe et al., 2011). This study presented disagreement of morphological and molecular characterisation, which resulted in opposition to a study on Fusarium species by Trabelsi et al. (2017) in Tunisia.

$F$. solani, F. oxysporum and $F$. proliferatum have been previously reported to cause wilt disease in most cucurbit plants including pumpkin (Chehri et al., 2011; Najihah et al., 2017; Perez-Hernandez et al., 2017; Rezaee et al., 2018). Once the pathogen is present at the root surface, it penetrates through natural openings and grows into the root cortex. After then, the infection progresses and colonises the xylem vessels. By this stage, it is ready to invade the upper ground structure of the plants (De Sain and Rep, 2015). Fusarium sp. secretes a plethora of effectors that enhance colonisation in xylem vessels. These effectors are named Six (secreted in xylem) proteins that are internalised into plant cells (Francisco et al., 2018).

The extension of Fusarium wilt infection caused severe and dead pumpkin plants. The presence of mycelia on the soft infected stem can be observed as a severe symptom of infection. There are several factors that contribute to the severity of Fusarium infection. These include the environmental condition, irrigation (Chehri et al., 2011), climatic conditions (Zhang et al., 2014) temperature and oceanic air (Czembor et al., 2015).

\section{Conclusion}

The identification of Fusarium comprising morphological and phylogenetic analyses has revealed better species identification especially for the complex structure of taxonomic like Fusarium. A single piece of infected pumpkin plant has been seen inhabited by various species of Fusarium. These species displayed a wide degree of disease severities. Fusarium solani, $F$. oxysporum and $F$. proliferatum are the most important pathogens of wilt disease in pumpkin. From this study, a better Fusarium wilt management could be achieved by accessing the information on the factors affecting the pathogenesis of pathogenic Fusarium. Any biological and physiological factors of pumpkin such as growth rate should be examined upon Fusarium invasion. 


\section{Acknowledgement}

The study was partially supported by the Putra Grant IPS vot no. 9577700, Universiti Putra Malaysia (UPM) to Nur Ain Izzati M.Z. Asma A. with My PhD scholarship from the Ministry of Higher Education Malaysia.

Disclaimer: None.

Conflict of Interest: None.

Source of Funding: This research was funded by Universiti Putra Malaysia.

\section{References}

Aggarwal H and Kotwal N, 2009. Food used as ethno-medicine in Jammu. Ethno-Med. 3(1): 6568.

Alarcon-Aguilar FJ, Hernandez-Galicia E, CamposSepulveda, AE, Xolalpa-Molina S, Rivas-Vilchis JF, Vazquez-Carrillo LI and Roman-Ramos R, 2002. Evaluation of hypoglycemic effect of Cucurbita ficifolia Bouche (Cucurbitaceae) in different experiment models. J. Ethnopharmacol. 82(2-3): 185-189.

Azor M, Gene J, Cano J, and Guarro J, 2007. Universal in vitro antifungal resistance of genetic clades of Fusarium solani species complex. Antimicrob. Agents Chemother. 51(4): 15001503.

Callagan SE, Puno VI, Williams AP, Weir BS, Balmas V, Sengsoulichan K, Phantavong S, Keovorlajak T, Phitsanoukane P, Xomphouthilath $\mathrm{P}$, Phapmixay KS, Vilavong S, Liew ECY, Duckitt GS and Burgess LW, 2016. First report of Fusarium oxysporum f.sp. niveum in the Lao PDR. Australas. Plant. Dis. Notes. 11: 9. DOI 10.1007/s13314-016-0191-8.

Caroline FA and Olubukola OB, 2013. Integrated management strategies for tomato Fusarium wilt. Biocontrol Sci.18(3): 117-127.

Chehri K, Salleh B, Yli-Matilla T, Reddy KRN and Abbasi S, 2011. Molecular characterization of pathogenic Fusarium species in cucurbit plants from Kermanshah province, Iran. Saudi J. Biol. Sci. 18(4): 341-351.

Czembor E, Stepien L and Waskiewicz A, 2015. Effect of environmental factors on Fusarium species and associated mycotoxins in maize grain grown in Poland. PLOS One. 10(7): 1-18.
De Sain M and Rep M, 2015. The role of pathogensecreted proteins in fungal vascular wilt disease. Int. J. Mol. Sci. 16: 23970-23993.

Ferriol M, Pico B and Nuez F, 2003. Genetic diversity of germplasm collection of Cucurbita pepo using SRAP and AFLP markers. Theor. Appl. Genet. 107: 271-282.

Francisco JDL, Maria EC, David HF, Shjef B, Martijn R and Fran WLT, 2018. Xylem sap proteomics reveals distinct differences between $\mathrm{R}$ gene- and endophyte-mediated resistances against Fusarium wilt disease in tomato. Front. Microbiol. 9: 1-13.

Geiser DM, Jimenez-Gasco MM, Kang S, Makalowska I, Veeraraghavan N, ard TJ, Zhang N, Kuldau GA and O'Donnell K, 2004. FUSARIUM-ID v. 1.0; A DNA sequence database for identifying Fusarium. Eur. J. Plant Pathol. 110: 473-479.

Hafizi R, Salleh B and Latiffah Z, 2013. Morphological and molecular characterization of Fusarium solani and $F$. oxysporum associated with crown disease of oil palm. Braz. J. Microbiol. 44(3): 959-968.

Kumar P, Kamle M, Misra AK, O'Donovan A, Pagano M and Modi DR, 2016. Identification and characterization of Fusarium mangiferae as pathogen of mango malformation in India. Braz. Arch. Biol. Technol. 59: 1-9.

Kusai NA, Ayob Z, Maidin MST, Safari S and Ahmad Ali SR, 2018. Characterization of fungi from different ecosystems of tropical peat in Sarawa, Malaysia. Rend. Lincei-Sci. Fis. 29(2): 469-482.

Leslie JF and Summerell BA, 2006. The Fusarium laboratory manual. (Ed). Blackwell Publishing, USA. pp. 2-20.

Liu J, Yu Y, Cai Z, Bartlam M and Wang Y, 2015. Comparison of ITS and 18S rDNA for estimating fungal diversity using PCR-DGGE. World. J. Microbiol. Biotechnol. 31:1387-1395

Liu H, Song C and Ram A, 2017. Advances in applied biotechnology: Proceedings of the $3^{\text {rd }}$ International Conference on Applied Biotechnology (ICAB2016), Pp. 589. In Proceedings, November 25-27, 2016, Tianjin, China. Springer Nature Singapore Pte Ltd.

Mahmood R, Pielke RA, Noyogi D and Dirmeyer P, 2014. Land cover changes and their biogeophysical effects on climate. Int. J. Climatol. 34: 929-953. 
Medjakovic S, Hobiger S, Ardjomand-Woelkart K, Bucar F and Jungbauer A, 2016. Pumpkin seed extract: cell growth inhibition of hyperplastic and cancer cells, independent of steroid hormone receptors. Fitoterpia. 110: 150-156.

MOA (Ministry of Agriculture Malaysia), 2018. Booklet statistik tanaman: sub-sektor tanaman makanan 2018. Wilayah Persekutuan Putrajaya, Malaysia.

Moreno-Velandia CA, Izquierdo-Garcia LF, Ongena M, Kloepper JW and Cotes AM, 2019. Soil sterilization, pathogen and antagonist concentration affect biological control of Fusarium wilt of cape gooseberry by Bacillus velezensis Bs006. Plant. Soil. 435(1-2): 39-55.

Mwaniki PK, Abang MM, Wagara IN, Wolukau JN and Schroers HJ, 2011. Morphology, pathogenicity and molecular identification of Fusarium spp. from wilting eggplants in Tanzania. Afr. Crop Sci. Conf. Proceed. 10: $217-$ 221.

Najihah A, Nur Ain Izzati MZ, Yong SYC and Nik Mohd Iham MN, 2017. Characterization of Fusarium proliferatum and Fusarium verticillioides based on species-specific gene and microsatellites analysis. Sains. Malays. 46(12): 2425-2432.

Nelson PE, Toussoun TA and Marasas WFO, 1983. Fusarium species: An Illustrated manual for identification, University Park, Pennsylvania State University Press 1983. pp. 51-171

O’Donnell K and Cigelnik E, 1997. Two divergent intragenomic rDNA ITS2 types within a monophyletic lineage of the fungus Fusarium are nonorthologous. Mol. Phylogenet. Evol. 7(1): 103-116.

Otero-Colina G, Rodriguez-Alvarado G, FernandezPavia S, Maymon M, Ploetz RZ, Aoki T, O'Donnell K and Freeman S, 2010. Identification and characterization of novel etiological agent of mango malformation disease in Mexico, Fusarium mexicanum sp. Phytopathol. 100(10): 1176-1184.

Perez-Hernandez A, Prcel-Rodriguez E and GomezVazguez J, 2017. Survival of Fusarium solani f.sp. cucurbitae and fungicide application, soil solarization and biosolarization for control of crown and foot rot of Zucchini squash. Plant. Dis. 101: 1507-1514.

Raupach GS, Liu L, Murphy JF, Tuzun S and Kloepper JW, 1996. Induced resistance in cucumber mosaic virus using plant growth promoting rhizobacteria. Plant. Dis. 80: 891-894.

Redda ET, Ma J, Mei J, Li M, Wu B and Jiang X, 2018. Antagonistic potential of different isolates of Trichoderma against Fusarium oxysporum, Rhizoctonia solani and Botrytis cinerea. Eur. J. Exp. Biol. 8(2): 1-8.

Rezaee S, Gharanjik S and Mokerlou S, 2018. Identification of Fusarium solani f.sp. cucurbitae races using morphological and molecular approaches. J. Crop Prot. 7(2): 161-170.

Sanders IR and Rodriguez A, 2016. Aligning molecular studies of mycorrhizal fungal diversity with ecologically important levels of diversity in ecosystems. ISME J. 10:2783-2786.

Schoonhoven AV and Pastor-Corrales MA, 1994. Standard system for the evaluation of bean germplasm. International Center of Tropical Agriculture (CIAT), California, Columbia. pp. 39.

Snyder WC, and Hansen HN, 1940. The species concept in Fusarium. Am. J. Bot. 27: 64-67.

Stevenson D, Fred JE, Wang L and Jane JL, 2007. Oil and tocopherol content and composition of pumpkin seed oil in 12 cultivars. J. Agric. Food Chem. 55(10): 4005-4013.

Sukanya R and Jayalakshmi SK, 2017. Response of inoculation technique to seed and seedling infection by $M$. phaseolina in Sorghum. Adv. Plants. Agric. Res. 6(1): 00198.

Summerell BA, Salleh B and Leslie JF, 2003. A utilitarian approach to Fusarium identification. Plant Dis. 87(2): 117-128.

Trabelsi R, Sellami H, Gharbi Y, Krid S, Cheffi M, Kammoun S, Dammak M, Mseddi A, Gdoura R and Triki MA, 2017. Morphological and molecular characterization of Fusarium spp. associated with olive trees dieback in Tunisia. Biotech. 7(1): 28-37.

Turrini A, Agnolucci M, Palla M, Tomé E, Tagliavini M, Scandellari F, Giovannetti M, 2017. Species diversity and community composition of native arbuscular mycorrhizal fungi in apple roots are affected by site and orchard management. Appl. Soil. Ecol. 116:42-54.

Van Dam P, Fokkens L, Schmidt SM, Jasper HJ, Linmans H, Kritler C, Ma LJ, Rep M, 2016. Effector profiles distinguish formae speciales of Fusarium oxysporum. Environ. Microbiol. 18: 4087-4102.

Watanabe M, Yonezawa T, Lee K, Kumagai S, Sugita-Konishi Y, Goto K and Hara-Kudo Y, 
2011. Molecular phylogeny of the higher and lower taxonomy of the Fusarium genus and differences in the evolutionary histories of multiple genes. Evol. Biol. 11(1): 322-338.

Zhang Y, Yu L, Yung KF, Leung DYC, Sun F and Lim BL, 2012. Overexpression of AtPAP2 in Camelina sativa leads to faster plant growth and higher seed yield. Biotechnol. Biofuel. 5: 19.

Zhang X, Halder J, White RP, Hughes Z, Ye C, Wang R, Gan B and Fitt BDL, 2014. Climate change increases risk of Fusarium ear blight on wheat in central China. Ann. App. Biol. 164: 384-395.

\section{Contribution of Authors}

Aris A: Conceived idea, literature review, data collection and manuscript writing

Hasan ZAE: Conceived idea, literature review and manuscript writing

Shohaimi S: Designed research methodology, data interpretation and statistical analysis

Saidi NB: Designed research methodology, data interpretation and statistical analysis

Zainudin NAIM: Conceived idea, designed research methodology, data interpretation, statistical analysis, manuscript final editing and approval 